\title{
"Too complex for me!" Why do performance-approach and performance-avoidance goals predict exam performance?
}

\author{
Céline Darnon \\ Clermont Université, France
}

Fabrizio Butera

Université de Lausanne, Switzerland

Gabriel Mugny

Alain Quiamzade

Université de Genève, Switzerland

Chris S. Hulleman

Vanderbilt University, U.S.A.

\begin{abstract}
Classroom research on achievement goals has revealed that performance-approach goals (goals to outperform others) positively predict exam performance whereas performance-avoidance goals (goals not to perform more poorly than others) negatively predict it. Because prior classroom research has primarily utilized multiplechoice exam performance, the first aim of the present study was to extend these findings to a different measure of exam performance (oral examination). The second aim of this research was to test the mediating role of perceived difficulty. Participants were 49 4th year psychology students of the University of Geneva. Participants answered a questionnaire assessing their level of performance-approach and performance-avoidance goal endorsement in one of their classes as well as the perceived difficulty of this class for themselves. Results indicated that performance-approach goals significantly and positively predicted exam grades. Performance-avoidance goals significantly and negatively predicted grades. Both of these relationships were mediated by the perceived difficulty of the class for oneself. Thus, the links
\end{abstract}

This work was supported by the Swiss National Science Foundation. Correspondence concerning this article should be addressed to Céline Darnon, Laboratoire de Psychologie Sociale et Cognitive, Université Blaise Pascal, 34 , Avenue Carnot, 63037 Clermont-Ferrand Cedex, France. Email: celine.darnon@univ-bpclermont.fr. 
previously observed between performance goals and exam performance were replicated on an oral exam. Perceived difficulty is discussed as a key dimension responsible for these findings.

For several years researchers have considered that students who are engaged in achievement tasks may endorse two different types of goals (Ames, 1992; Dweck, 1986; Nicholls, 1984). Mastery goals are defined as a focus on improving one's own competence, learning, and mastering the task. Performance goals are defined as the general desire to do well in comparison with others. The authors agreed in arguing that mastery goals lead to many adaptive outcomes, such as task persistence after failure (Diener \& Dweck, 1980), intrinsic interest (Rawsthorne \& Elliot, 1999), low reports of disruptive behaviours (Kaplan, Gheen, \& Midgley, 2002) and efficient modes of conflict regulation (Darnon \& Butera, 2007; Darnon, Muller, Schrager, Pannuzzo, \& Butera, 2006). However, there has been less consensus on the effects of performance goals (e.g., Harackiewicz, Barron, \& Elliot, 1998; Harackiewicz, Barron, Pintrich, Elliot, \& Thrash, 2002; Midgley, Kaplan, \& Middleton, 2001; Pintrich, 2003).

More recent models of achievement goals have specified that performance goals could have two different forms (Elliot, 1997; Elliot \& Harackiewicz, 1996). If individuals are oriented toward outperforming others (trying to obtain positive judgements), then they are pursuing performance-approach goals. In contrast, if they are oriented toward avoiding performing more poorly than others (avoiding negative judgements), then they are pursuing performance-avoidance goals (Elliot, 1997, 1999; Elliot \& Church, 1997; Elliot \& Harackiewicz, 1996; Middleton \& Midgley, 1997). This distinction permits greater specificity in predicting the effects of performance goals. Research shows that performance-avoidance goals are linked to many maladaptive outcomes, including academic performance (Church, Elliot, \& Gable, 2001; Elliot \& Church, 1997; Elliot \& McGregor, 1999, 2001; Elliot, McGregor, \& Gable, 1999; McGregor \& Elliot, 2002; Sideridis, 2005), whereas performanceapproach goals are often positively linked to exam performance (Bouffard, Boisvert, Vezeau, \& Larouche, 1995; Church et al., 2001; Elliot \& Church, 1997; Elliot \& McGregor, 1999, 2001; Elliot et al., 1999; Harackiewicz, Barron, Carter, Lehto, \& Elliot, 1997; Harackiewicz, Barron, Tauer, \& Elliot, 2002; Pintrich, 2000; Sideridis, 2005; Wolters, Yu, \& Pintrich, 1996; for reviews, see Barron \& Harackiewicz, 2000; Harackiewicz, Barron, Pintrich, et al., 2002). This link was even observed on long-term measures of academic performance (Harackiewicz, Barron, Tauer, Carter, \& Elliot, 2000) and in advanced undergraduate seminars (Barron \& Harackiewicz, 2003).

The above results run counter to the traditional view that performance goals are "negative goals" that should be avoided as much as possible in the classroom (e.g., Ames, 1992; Dweck \& Legett, 1988), and have led to a debate in the literature as to the reason for the positive performance goals - grade link (Harackiewicz, Barron, Pintrich, et al., 2002; Kaplan \& Midgley, 2002; Midgley et al., 2001; see also Senko, Durik, \& Harackiewicz, 2007). Among the arguments put forward to explain this positive link is the way academic performance is assessed. Indeed, it is argued that a limitation of many studies performed in college classrooms is that exam performance is assessed using multiple choice questionnaires consisting of "completing repetitive work, being compliant, well-behaved, or generally exhibiting a surface level understanding of the material" (Wolters, 2004, p. 248). This kind of exam can be considered as not reflecting the students' deep understanding of the course and instead as an indication of an efficient, surface mode of studying (for example, trying to learn only what is necessary for the exam). According to Harackiewicz et al. (1997), "a superficial approach to learning may actually be quite effective in preparing for multiple choice exams in introductory classes. If college examinations do not test for deep processing or thoughtful synthesis and integration, then performance oriented students may be the ones most likely to obtain good grades" (p. 1292; see also Harackiewicz et al., 1998, 2000; Wolters, 2004, for similar discussions). Thus, in order to test this explanation, it is important to examine if the 
performance-approach goals - grade link is also valid for a different kind of exam, one that necessitates a great deal of reflection upon the studied materials. This validation will be the first aim of the present study, where the students underwent an oral examination which required them not only to recall important information, but also to interpret, analyze, and integrate the course material during an oral presentation (see "Methods" for more detail).

The second aim of the study is to contribute to explain this effect, and in particular to find a suitable mediator. As Harackiewicz et al. (1998) noted, "Another limitation of our classroom research is that we did not examine the process that mediated the goal effect we observed" (p. 17). Following this recommendation, some authors have examined possible mediators of these links. Notably, Elliot et al. (1999) found that the negative link between performanceavoidance goals and exam performance was mediated by disorganization, whereas the positive link between performance-approach goals and exam performance was mediated by persistence and effort. In addition, Elliot and McGregor (1999) observed that the link between performance-avoidance and exam performance was mediated by state test anxiety. This was not the case for performance-approach goals. The present study aims to extend these results by examining a variable that could mediate the links between both types of performance goals and exam performance: perceived difficulty.

In trying to understand why performance-approach and performance-avoidance goals have different relationships with educational outcomes, Elliot (1999; Elliot \& Church, 1997) examined the antecedents of these goals. For Elliot, the disruptive component of performance goals (both approach and avoidance) is their association with fear of failure (see also Rawsthorne \& Elliot, 1999). The association with fear of failure helps explain why performanceavoidance goals are linked to negative outcomes. Although performance-approach goals are also linked to fear of failure, they are also associated to more positive motivational antecedents, such as competence expectancies (Elliot \& Church, 1997). More precisely, according to these authors, individuals with high competence expectancies would be more likely to adopt performance-approach goals, whereas those with low competence expectancies would be more likely to adopt performance-avoidance goals. The high competence expectancies may buffer the individual from the negative effects of fear of failure, and thus allow performance-approach goals to be positively linked with outcomes.

Based on the above reasoning, then one can expect students who strongly adopt performance-approach goals to think that "they can do it." That is, they should think that the task is "reachable" for them. We argue that this could be the reason why those students perform well in classroom. In contrast, students who strongly endorse performance-avoidance goals may perform poorly because they may think that "they'll never manage to do it." That is, the task is considered too difficult for their own level of abilities. If the reasoning is correct, the same mediator, namely, perceived difficulty for oneself, is expected to mediate the links between performance goals and performance. Specifically, the positive link between performance-approach goals and exam performance, and the negative link between performance-avoidance goals and exam performance, should both be mediated by perceived difficulty of the task.

\section{Overview and hypotheses}

In many studies, performance-approach goals positively predict exam performance, whereas performance-avoidance goals negatively predict it (e.g., Church et al., 2001; Elliot \& Church, 1997; Elliot \& McGregor, 1999). The first aim of the present study is to replicate these findings with an oral exam, i.e., a form of examination that requires students to evaluate and synthesize the material at a deeper level than most multiple-choice tests.

Moreover, the present study will also test the hypothesis that the links between performance goals (approach and avoidance) and exam performance are mediated by perceived difficulty. Because we think that the possible mediating dimensions is person- 
specific rather than a perceived difficulty of the class in general, we expect that the mediator will be the perceived complexity for oneself and not some general perceived complexity of the content of the class for this academic level.

\section{Method}

\section{Participants and procedure}

Participants were 69 fourth-year psychology students of the University of Geneva (Switzerland). They answered a questionnaire during one of their social psychology classes. Twenty participants were dropped from the sample because they had incomplete data (e.g., they did not come to the exam, or did not complete the questionnaire) or they appeared to have an uncommon studentized deleted residual ( $N=2$; Judd \& McClelland, 1989). Thus, the final sample consisted of 49 participants, including 35 women and 13 men (one did not report his/her sex), with a mean age of $24.8(S D=5.16)$. It is worth noting that in this study, the majority of participants are women, which reflects the distribution of students in psychology departments. However, all of the presented effects remained significant when controlling for the sex of participants. The questionnaire was answered in the middle of the semester. The exam took place at the end of the semester.

\section{Measures}

For all questionnaire items, participants were asked to report to what extent it was true for them (from 1 "not at all true for me" to 7 "very true for me").

Achievement goals scale. Participants responded to Elliot and McGregor's (2001) achievement goals questionnaire, validated in French by Darnon and Butera (2005). Only the three items of performance-approach goals (e.g., "It is important for me to do better than other students", $\alpha=.93$ ) and the three items of performance-avoidance goals (e.g., "My goal in this class is to avoid performing poorly", $\alpha=.70$ ) were used.

Perceived difficulty for oneself. This variable was operationalized by the item, "I consider that the content of this class is too complex for me."

General perceived difficulty. This variable was operationalized by the item "I consider that the content of this class is too complex for our academic level."

Initial academic performances. In order to control for the participants' initial academic performances, we asked them to report the number of exams that they failed the year before. This number ranged from 0 to 10 . It is important to note that even if self-reported measures of school success may be biased, they highly correlate with real grades (Chatard, Guimond, \& Selimbegovic, 2007).

Exam performance. Exam performance consisted of the regular social psychology exam. Each student was tested by the teacher and one of his assistants. Two questions were drawn by lot and the student could choose between them. The students then had 15 minutes to prepare their presentation, and then 15 minutes to explain and defend it. As the exam consisted of not only repeating what had been taught in the class, but also analyzing and interpreting this information, students were allowed to use any materials they needed (notes, books, etc.) during the preparation time. The questions asked by the teacher and his assistant during the presentation were elaborated in order to assess not only if students remembered the content of 
the class but also if they were able to integrate different concepts with one another, and to apply this knowledge to real life situations. The level of processing involved in this exam reflected the first five elements of Bloom's taxonomy (knowledge, comprehension, application, analysis, synthesis; Bloom, 1984). For example, students were asked to use some theories, presented at some point during the class, to explain other situations and results of other experiments presented later in the class. During the examination, the teacher and the assistant probed the student's understanding by asking several questions on the chosen topic and the rest of the class content and also by asking the student to compare and articulate different notions. Then, the teacher and his assistant decided independently on the grade to give the student, taking into account his/her knowledge of the class content and his/her ability to answer the questions. Most of the time, they agreed on the grade to assign. When they disagreed, they discussed the matter until they reached an agreement. The teacher and the assistant were unaware of the participant's answer on the achievement goals scale and the complexity items. The grade could range from 1 to 6 .

\section{Results}

Means, ranges, standard deviations and zero-order intercorrelations among variables are presented in Table 1.

Table 1

Descriptive statistics and intercorrelations among variables

\begin{tabular}{lcccccccc}
\hline & $M$ & $S D$ & Range & (1) & (2) & (3) & (4) & (5) \\
\hline Performance-approach goals (1) & 2.78 & 1.56 & $1-7$ & 1 & & & & \\
Performance-avoidance goals (2) & 3.86 & 1.42 & $1-7$ & .19 & 1 & & & \\
Exam performance (3) & 4.18 & 1.12 & $1-6$ & $.30^{*}$ & $-.33^{*}$ & 1 & & \\
Perception of the class as too complex for & & & & & & & & \\
oneself (4) & 3.65 & 1.63 & $1-7$ & -.25 & $.46^{* * *}$ & $-.55^{* * *}$ & 1 & \\
$\begin{array}{l}\text { Perception of the class as too complex for } \\
\text { this academic level (5) }\end{array}$ & & & & & & & & \\
Initial performance (6) & 3.18 & 1.62 & $1-7$ & -.16 & $.49^{* * *}$ & $-.32^{*}$ & $.70^{* * *}$ & 1 \\
\hline
\end{tabular}

Note. ${ }^{*} p<.05 ; * * p<.01 ; * * * p<.001 ; N=49$.

\section{Overview of the analyses}

Simultaneous multiple regression analyses were conducted to examine the effect of performance-approach goals, performance-avoidance goals, and their interaction on exam performance. The measure of initial academic performances was entered in the analyses as a covariate. Since none of the independent variables were significantly correlated to the covariate, the interaction between the covariate and the independent variables were not retained in the final model (see Muller, Yzerbyt, \& Judd, 2008; Yzerbyt, Muller, \& Judd, 2004). The final regression model contained 4 terms: the two performance goals, their interaction, and initial academic performance.

\section{Predictors of exam performance}

Regressing exam performance on the model indicated that the overall model was significant $F(4,44)=4.94, p<.003, \eta^{2}=.31$. Exam performance was positively predicted by 
performance-approach goals, $B=.29, F(1,44)=9.58, p<.004, \eta^{2}=.18$, and negatively predicted by performance-avoidance goals, $B=-.27, F(1,44)=6.65, p<.02, \eta^{2}=.13$. The interaction was not significant, $F<1$.

\section{Mediation effects}

To test the mediation effect, we used the methodology recommended by Baron and Kenny (1986). First, the dependent variable (exam performance) was regressed on the model (including performance-approach, performance-avoidance, the interaction and measure of initial academic performance; cf. previous section). Then, the mediator was regressed on the same model. Finally, the same model as in step 1 was tested, with the inclusion of the mediator variable (in the present case, with perceived complexity).

For performance-approach goals (1) performance-approach goals positively predicted the dependent variable (exam performance), as shown in the previous section; (2) performanceapproach goals negatively predicted the mediator (perceived complexity for oneself), $B=-.45$, $F(1,44)=14.01, p<.001, \eta^{2}=.24$; (3) perceived complexity predicted exam performance even when controlling for the effect of performance-approach goals, $B=-.24, F(1,43)=4.64, p<.04$, $\eta^{2}=10$. The effect of performance-approach goals on exam performance was not significant when controlling for the effect of the mediator, $B=.18, F(1,43)=3.05, p<.09 ; \eta^{2}=.07$.

For performance-avoidance goals (1) performance-avoidance goals negatively predicted exam performance, as shown in the previous section; (2) performance-avoidance goals positively predicted perceived complexity for oneself, $B=.49, F(1,44)=13.48, p<.001, \eta^{2}=.23$; (3) perceived complexity predicted exam performance even when controlling for the effect of performance-avoidance goals, $B=-.24, F(1,43)=4.64, p<.04, \eta^{2}=.10$. The link between performance-avoidance goals and exam performance was not significant when controlling for the effect of the mediator, $B=-.15, F(1,43)=1.7, p<.20, \eta^{2}=.04$.

In order to verify that the above mediation effects were not due to the perceived complexity of the class in general, the above analyses were repeated with the measure of perceived "complexity of the content of the class for our academic level". The mediational role of general perceived complexity was not verified: This variable did not predict exam performance $(F<1)$, nor did it change the effect of performance-approach goals, $B=.29$, $F(1,43)=8.17, p<.007, \eta^{2}=.16$, or performance-avoidance goals, $B=-.26, F(1,43)=4.59, p<.04$, $\eta^{2}=.10$. The results are summarized in Figure 1 .

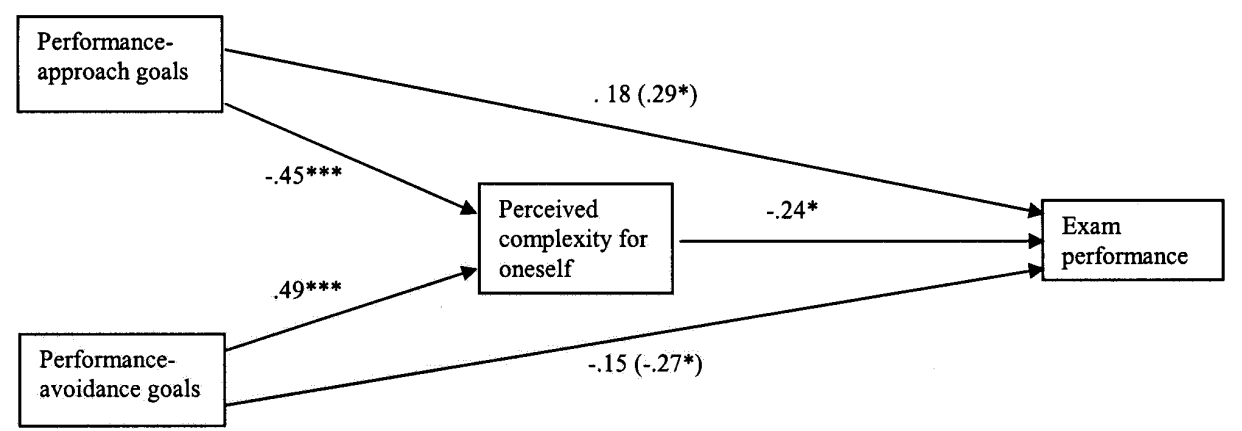

Figure 1. Relationship between performance goals (approach and avoidance) and exam performance, with and without control for perceived complexity for oneself.

Note. Values indicate non-standardized regression coefficients $(B)$ with and without (in brackets) the control of perceived complexity for oneself. $* p<.05 ; * *<.01 ; * * *<<.001$. 
In sum, these analyses showed that the perception of the content of the class as too complex for oneself, and not the perception of the class as too complex for any student at this academic level, partially mediated the effects of both performance-approach and performanceavoidance goals on exam performance.

\section{Discussion}

The present study replicated the links between performance goals and exam performance found in previous research (Church et al., 2001; Elliot \& Church, 1997; Elliot \& McGregor, 1999, 2001; Elliot et al., 1999; Harackiewicz et al., 1997, 2000; Pintrich, 2000; Wolters et al., 1996). As mentioned earlier, in most of those studies this link was observed on a multiplechoice test, a measure of performance that can be considered as reflecting surface rather than deep learning. Interestingly, Barron and Harackiewicz (2003) observed the same link in advanced classes that required a deeper level of understanding. The present research supports this latter finding. Indeed, our results indicate that the positive link between performanceapproach goals and exam performance as well as the negative link between performanceavoidance goals and exam performance were observed when performance was measured through an oral exam (a recall/integration-based task), instead of a multiple choice exam (a primarily recognition-based task). Thus, our results indicate that the positive link between performance-approach goals and exam performance is observed even when the exam requires a deeper level of learning.

The mediation analyses showed that students who adopted higher levels of performanceapproach goals performed better on the exam because they perceived the content of the class as being not "too complex" for themselves. In contrast, students who adopted higher levels of performance-avoidance goals performed more poorly because they perceived the content of the class as "too complex" for themselves. Importantly, it was perceived complexity for oneself, rather than general perceived complexity, that mediated the performance goal effects on oral exam performance.

The mediation results are congruent with recent research showing the importance of uncertainty in understanding performance goals effects (e.g., Darnon, Harackiewicz, Butera, Mugny, \& Quiamzade, 2007). They support the idea that one's perception of ability to do the task is a key contributor. Indeed, the present study indicates that goal adoption leads to perceiving the task as "reachable", in the case of performance-approach goals, or as too difficult, in the case of avoidance goals. These perceptions of difficulty then impact task performance and, in the case of performance-approach goals, provide a buffer against the detrimental effects of fear of failure.

As suggested by Dweck and Legett (1988), in a context where performance goals are prevalent, failure is meaningful since it is perceived as an indication that abilities are low. As a consequence, both performance-approach and performance-avoidance goals are associated with the possibility of failure. However, performance-approach and performance-avoidance goals are not associated with the same types of coping in failure-salient situations. In line with Elliot's model (1997), students who adopt performance-approach goals in these situations may be buffered against the fear of failure because they perceive the task as within their range of abilities (i.e., not "too complex for themselves"), and thus are able to perform well. On the contrary, students who adopt performance-avoidance goals are not buffered against their fear of failure. Instead, their focus on avoiding failure may lead them to perceive the task as outside their range of abilities (i.e., "too complex for themselves"). Because of these foci, they do not perform well on the task.

Some limitations may be noted concerning this study. Notably, the mediator was a single item measure and needs to be validated or replaced by additional measures of task difficulty. In the same vein, the same analyses should be repeated with the inclusion of a more accurate measure of initial academic performance than the one used in the present study, and on a larg- 
er sample. More importantly, it would be interesting to examine the similarities between this measure and other measures such as self efficacy (Bandura, 1977), competence expectancies (Elliot \& Church, 1997), and fear of failure (Elliot \& Church, 1997). Future research will need to examine the inter-relationships between our measure of perceived difficulty and these other potential mediators. Finally, it is argued that performance goals affect task difficulty, which in turn affects performance. However, the present study is not sufficient to make sure that a causal link exists between these variables. Notably, and consistently with the existing literature (e.g., Elliot \& Church, 1997), one could argue that competence expectancy is the key factor predicting both goals and perceived complexity. Additional research is needed to establish a causal link between goals and task complexity. As an example, a study with an experimental manipulation of performance goals could allow clarifying this point.

Notwithstanding these limitations, this research permits a better understanding of the link between performance goals and academic achievement. We have mentioned earlier how often these effects were observed and how important it was to explain them. One explanation offered for these findings is that the measure of exam performance has been limited to surface-level questions, and that the performance goals - grade link would not be found if the exam required deeper processing. Our results do not support this explanation. Instead, our results support that reported by Barron and Harackiewicz (2003) demonstrating that performance goal effects are maintained in courses and exams that require deeper processing. In addition, our results underline the importance of perceived difficulty for oneself in explaining these results. Overall, these results help to clarify the relationship between performance goals and exam performance, a question that is central in the achievement goal literature (Senko et al., 2007).

\section{References}

Ames, C. (1992). Classrooms: Goals, structures, and students motivation. Journal of Educational Psychology, 84, 261-271.

Bandura, A. (1977). Self-efficacy: Toward a unifying theory of behavioral change. Psychological Review, 84, 191-215.

Baron, R.M., \& Kenny, D.A. (1986). The moderator-mediator variable distinction in social psychological research: Conceptual, strategic, and statistical considerations. Journal of Personality and Social Psychology, 51, 1173-1182.

Barron, K.E., \& Harackiewicz, J.M. (2000). Achievement goals and optimal motivation: A multiple goals approach. In C. Sansone \& J.M. Harackiewicz (Eds.), Intrinsic and extrinsic motivation: The search for optimal motivation and performance (pp. 229-254). San Diego, CA: Academic Press.

Barron, K.E., \& Harackiewicz, J.M. (2003). Revisiting the benefits of performance-approach goals in the college classroom: Exploring the role of goals in advanced college courses. International Journal of Educational Research, 39, 357-374.

Bloom, B.S. (1984). Taxonomy of educational objectives. Allyn and Bacon, Boston, MA.

Bouffard, T., Boisvert, J., Vezeau, C., \& Larouche, C. (1995). The impact of goal orientation on self regulation and performance among college students. British Journal of Educational Psychology, 65, 317-329.

Chatard, A., Guimond, S., \& Selimbegovic, L. (2007). "How good are you in math?” The effect of gender stereotypes on students' recollection of their school marks. Journal of Experimental Social Psychology, 43, 1017-1024.

Church, M.A., Elliot, A.J., \& Gable, S.L. (2001). Perceptions of classroom environment, achievement goals, and achievement outcomes. Journal of Educational Psychology, 93, 43-54.

Darnon, C., \& Butera, F. (2005). Buts d'accomplissement, stratégies d'étude, et motivation intrinsèque: présentation d'un domaine de recherche et validation française de l'échelle d'Elliot et McGregor (2001) [Achievement goals, study strategies, and intrinsic motivation: Presenting a domain of research and the French validation of Elliot \& McGregor's scale]. L'Année Psychologique, 105, 105-131.

Darnon, C., \& Butera, F. (2007). Learning or succeeding? Conflict regulation with mastery or performance goals. Swiss Journal of Psychology, 66, 145-152. 
Darnon, C., Harackiewicz, J., Butera, F., Mugny, G., \& Quiamzade, A. (2007). Performance-approach and performanceavoidance goals: When uncertainty makes a difference. Personality and Social Psychology Bulletin, 33, 813-827.

Darnon, C., Muller, D., Schrager, S.M., Pannuzzo, N., \& Butera, F. (2006). Mastery and performance goals predict epistemic and relational conflict regulation. Journal of Educational Psychology, 98, 766-776.

Diener, C.I., \& Dweck, C.S. (1980). An analysis of learned helplessness II: The processing of success. Journal of Personality and Social Psychology, 39, 940-952.

Dweck, C.S. (1986). Motivational processes affecting learning. American Psychologist, 41, 1040-1048.

Dweck, C.S., \& Leggett, E.L. (1988). A social-cognitive approach to motivation and personality. Psychological Review, 95, 256-273.

Elliot, A.J. (1997). Integrating the "classic" and "contemporary" approaches to achievement motivation: A hierarchical model of approach and avoidance motivation. In M. Maehr \& P. Pintrich (Eds.), Advances in motivation and achievement (vol. 10, pp. 143-179). Greenwich, CT: JAI.

Elliot, A.J. (1999). Approach and avoidance motivation and achievement goals. Educational Psychologist, 34, 169-189.

Elliot, A.J., \& Church, M.A. (1997). A hierarchical model of approach and avoidance achievement motivation. Journal of Personality and Social Psychology, 72, 218-232.

Elliot, A.J., \& Harackiewicz, J.M. (1996). Approach and avoidance achievement goals and intrinsic motivation: A mediational analysis. Journal of Personality and Social Psychology, 70, 461-475.

Elliot, A.J., \& McGregor, H.A. (1999). Test anxiety and the hierarchical model of approach and avoidance achievement motivation. Journal of Personality and Social Psychology, 76, 628-644.

Elliot, A.J., \& McGregor, H.A. (2001). A $2 * 2$ achievement goal framework. Journal of Personality and Social Psychology, 80, 501-519.

Elliot, A.J., Mc Gregor, H.A., \& Gable, S. (1999). Achievement goals, study strategies, and exam performance: A mediational analysis. Journal of Educational Psychology, 91, 549-563.

Harackiewicz, J.M., Barron, K.E., \& Elliot, A.J. (1998). Rethinking achievement goals: When are they adaptive for college students and why? Educational Psychologist, 33, 1-21.

Harackiewicz, J.M., Barron, K.E., Tauer, J.M., \& Elliot, A.J. (2002). Predicting success in college: A longitudinal study of achievement goals and ability measures as predictors of interest and performance from freshman year through graduation. Journal of Educational Psychology, 94, 562-575.

Harackiewicz, J.M., Barron, K.E., Carter, S.M., Lehto, A.T., \& Elliot, A.J. (1997). Predictors and consequences of achievement goals in the college classroom: Maintaining interest and making the grade. Journal of Personality and Social Psychology, 73, 1284-1295.

Harackiewicz, J.M., Barron, K.E., Pintrich, P.R., Elliot, A.J., \& Thrash, T.M. (2002). Revision of achievement goal theory: Necessary and illuminating. Journal of Educational Psychology, 94, 638-645.

Harackiewicz, J.M., Barron, K.E., Tauer, J.M., Carter, S.M., \& Elliot, A.J. (2000). Short-term and long-term consequences of achievement goals: Predicting interest and performance over time. Journal of Educational Psychology, 92, 316-330.

Judd, C.M., \& McClelland, G.H. (1989). Data analysis: A model comparison approach. San Diego: Harcourt, Brace, Jovanovich.

Kaplan, A., \& Midgley, C. (2002). Should childhood be a journey or a race? Response to Harackiewicz et al. (2002). Journal of Educational Psychology, 94, 646-648.

Kaplan, A., Gheen, M., \& Midgley, C. (2002). Classroom goal structure and student disruptive behaviour. British Journal of Educational Psychology, 72, 191-211.

McGregor, H., \& Elliot, A.J. (2002). Achievement goals as predictors of achievement-relevant processes prior to task engagement. Journal of Educational Psychology, 94, 381-395.

Middleton, M., \& Midgley, C. (1997). Avoiding the demonstration of lack of ability: An underexplored aspect of goal theory. Journal of Educational Psychology, 89, 710-718.

Midgley, C., Kaplan, A., \& Middleton, M. (2001). Performance-approach goals: Good for what, for whom, under what circumstances, and at what cost? Journal of Educational Psychology, 93, 77-86. 
Muller, D., Yzerbyt, V., \& Judd, C.M. (2008). Adjusting for a mediator in models with two crossed treatment variables. Organizational Research Methods, 11, 224-240.

Nicholls, J.G. (1984). Achievement motivation: Conceptions of ability, subjective experience, task choice, and performance. Psychological Review, 91, 328-346.

Pintrich, P. (2000). Multiple goals, multiple pathways: The role of goal orientation in learning and achievement. Journal of Educational Psychology, 92, 544-555.

Pintrich, P. (2003). A motivational science perspective on the role of student motivation in learning and teaching contexts. Journal of Educational Psychology, 95, 667-686.

Rawsthorne, L., \& Elliot, A. J. (1999). Achievement goals and intrinsic motivation: A meta-analytic review. Personality and Social Psychology Review, 3, 326-344.

Senko, C.M., Durik, A.M., \& Harackiewicz, J.M. (2007). Historical perspectives and new directions in achievement goal theory: Understanding the effects of mastery and performance-approach goals. In J.Y. Shah \& W. Gardner (Eds.), Handbook of Motivation Science. New York: Guilford.

Sideridis, G.D. (2005). Goal orientation, academic achievement, and depression: Evidence in favor of a revised goal theory framework. Journal of Educational Psychology, 97, 366-375.

Wolters, C.A. (2004). Advancing achievement goal theory: Using goal structures and goal orientations to predict students' motivation, cognition, and achievement. Journal of Educational Psychology, 96, 236-250.

Wolters, C.A., Yu, S.L., \& Pintrich, P.R. (1996). The relation between goal orientation and students' motivational beliefs and self-regulated learning. Learning and Individual Differences, 8, 211-238.

Yzerbyt, V., Muller, D., \& Judd, C.M. (2004). Adjusting researchers' approach to adjustment: On the use of covariates when testing interactions. Journal of Experimental Social Psychology, 40, 424-431.

Les recherches sur les buts d'accomplissement ont montré que les buts de performance-approche (réussir mieux que les autres) prédisent positivement la performance alors que les buts de performanceévitement (ne pas réussir moins bien que les autres) la prédisent négativement. Celles-ci ayant principalement utilisé des examens à choix multiples, le premier objectif de la présente étude était d'étendre ces résultats à une mesure différente de performance (examen oral). Le second objectif de cette recherche était de tester le rôle médiateur de la difficulté perçue. Les participants étaient 49 étudiants de 4ème année de psychologie de l'Université de Genève. Les participants ont répondu à un questionnaire mesurant leur niveau de buts de performanceapproche et performance-évitement dans l'une de leur classe, ainsi que leur perception du niveau de difficulté de cette classe. Les résultats indiquent que les buts de performance-approche prédisent de manière significative et positive la note obtenue à l'examen. Les buts de performance-évitement la prédisent négativement. Ces deux relations sont médiatisées par la difficulté perçue de la tâche pour soi. Ainsi, les liens obtenus au préalable entre buts de performance et performance à l'examen sont répliqués sur un examen oral. La difficulté perçue est discutée comme la dimension clé responsable de ces liens.

Key words: Oral examination, Perceived difficulty, Performance-approach goals, Performance-avoidance goals. 
Céline Darnon. Clermont Université, Université Blaise Pascal, Laboratoire de Psychologie Sociale et Cognitive-UMR CNRS 6024, 34 avenue Carnot, 63037 Clermont-Ferrand Cedex, France. E-mail: celine.darnon@univ-bpclermont.fr; Web site: www.psy.univ-bpclermont.fr/lapsco/

Current theme of research:

Effects of achievement goals on performance and conflict regulation, social value of achievement goals at university, mastery vs. performance form of academic assessment.

Most relevant publications in the field of Psychology of Education:

Darnon, C., Butera, F., \& Harackiewicz, J. (2007). Achievement goals in social interactions: Learning with mastery vs. performance goals. Motivation and Emotion, 31, 61-70.

Darnon, C., Butera, F., \& Harackiewicz, J.M. (Eds.). (2008). Toward a clarification of the effects of achievement goals. Special issue of the International Review of Social Psychology, 21. Grenoble: Presses Universitaires de Grenoble.

Darnon, C., Dompnier, B., Delmas, F., Pulfrey, C., \& Butera F. (2009). Achievement goal promotion at university: Social desirability and social utility of mastery and performance goals. Journal of Personality and Social Psychology, 96, 119-134.

Darnon, C., Harackiewicz, J., Butera, F., Mugny, G., \& Quiamzade, A. (2007). Performance-approach and performanceavoidance goals: When uncertainty makes a difference. Personality and Social Psychology Bulletin, 33(6), 813-827.

Darnon, C., Muller, D., Schrager, S.M., Butera, F., \& Pannuzzo, N. (2006). Mastery and performance goals predict epistemic and relational conflict regulation. Journal of Educational Psychology, 98, 766-776.

Fabrizio Butera. Laboratoire de Psychologie Sociale (UNILaPS), Université de Lausanne, SSP, Anthropole, CH 1015, Lausanne, Switzerland. E-mail: fabrizio.butera@unil.ch; Web site: www.unil.ch/ps/page41962_en.html

Current theme of research:

Cooperation and competition in cognition and behaviour.

Most relevant publications in the field of Psychology of Education:

Buchs, C., Butera, F., \& Mugny, G. (2004). Resource in(ter)dependence, student interactions and performance in cooperative learning. Educational Psychology, 24, 291-314.

Butera, F., \& Buchs, C. (2005). Reasoning together: From focussing to decentring. In V. Girotto \& P.N. Johnson-Laird (Eds.), The shape of reason (pp. 193-203). Hove, UK: Psychology Press.

Butera, F., Johnson, R., Johnson, D., \& Mugny, G. (Eds.). (2002). Learning at the University. Special issue of the Swiss Journal of Psychology, 61. Berne: Hans Huber.

Darnon, C., Butera, F., \& Mugny, G. (2008). Des conflits pour apprendre. Grenoble: Presses Universitaires de Grenoble.

Dompnier, B., Darnon, C., Delmas, F., \& Butera F. (2008). Achievement goals and social judgment: The performanceapproach goals paradox. International Review of Social Psychology, 21, 247-271.

Gabriel Mugny. University of Geneva, F.P.S.E., 40 bvd. du Pont d'Arve, 1205 Genève, Switzerland. E-mail: Gabriel.Mugny@unige.ch; Web site: www.unige.ch/fapse/psychosociale/master/ index.htm

Current theme of research:

Conflict elaboration, Social Influence, Social development of knowledge, Social representations. 
Most relevant publications in the field of Psychology of Education:

Chatard, A., Quiamzade, A., \& Mugny, G. (2007). Les effets de l'éducation sur les attitudes sociopolitiques des étudiants: Le cas de deux universités en Roumanie. L'Année Psychologique, 107(2), 225-237.

Chatard, A., Konan, P., Selimbegovic, L., \& Mugny, G. (2008). Performance boosts in the classroom: Stereotype endorsement and prejudice moderate stereotype lift. Journal of Experimental Social Psychology, 44, 1421-1424.

Doise, W., \& Mugny, G. (1984). The social development of the intellect. Oxford: Pergamon Press.

Falomir, J.M., \& Mugny, G. (2004). Société contre fumeur: Une analyse psychosociale de l'influence des experts. Grenoble: Presses Universitaires de Grenoble.

Mugny, G., \& Carugati, F. (1989). Social representations of intelligence. Cambridge: Cambridge University Press / Paris: Editions de la Maison des Sciences de l'Homme.

Alain Quiamzade. University of Geneva, 25 boulevard du Pont d'Arve, 1205 Geneva, Switzerland. E-mail: alain.quiamzade@unige.ch

Current theme of research:

Social influence, social comparison processes.

Most relevant publications in the field of Psychology of Education:

Chatard, A., Quiamzade, A., \& Mugny, G. (2007). Les effets de l'éducation sur les attitudes sociopolitiques des étudiants: Le cas de deux universités en Roumanie. L'Année Psychologique, 107, 225-237.

Quiamzade, A. (2007). Imitation and performance in confrontations between competent peers: The role of the representatio of the task. European Journal of Psychology of Education, XXII(3), 243-258.

Quiamzade, A., \& Mugny, G. (2001). Social influence dynamics in aptitude tasks. Social Psychology of Education, 4, 311-334.

Quiamzade, A., Mugny, G., \& Chatard, A. (2009). When teaching style matches students' epistemic (in)dependence: The moderating effect of perceived epistemic gap. European Journal of Psychology of Education, XXIV(3), 361-371.

Quiamzade, A., Mugny, G., \& Darnon, C. (2009). The coordination of problem solving strategies: When low competence sources exert more influence on task processing than high competence ones. British Journal of Social Psychology, 48, 159-182.

Chris Hulleman. Department of Psychology and Human Development, Peabody College, Peabody \#552, 230 Appleton Place, Vanderbilt University, Nashville, TN 37203, USA. E-mail: chris.hulleman@vanderbilt.edu; Web site: www.vanderbilt.edu/lsi/expert.html

Current theme of research:

Integrating expectancy-value, achievement goal, and interest theories; field research methodology; developing effective motivational interventions for the classroom.

Most relevant publications in the field of Psychology of Education:

Barron, K.E., \& Hulleman, C.S. (2006). Is there a formula to help understand and improve student motivation? Essays from E-xcellence in Teaching, Volume 8. Retrieved [August 5, 2006] from the Society for the Teaching of Psychology Web site: www.list.kennesaw.edu/archives/psychteacher.html

Bodmann, S.M., Hulleman, C.S., \& Harackiewicz, J.M. (2008). Achievement goal systems: An application of goal systems theory to achievement goal research. International Review of Social Psychology, 21, 71-96.

Hulleman, C.S., Durik, A.M., Schweigert, S., \& Harackiewicz, J.M. (2008). Task values, achievement goals, and interest: An Integrative analysis. Journal of Educational Psychology, 100, 398-416. 
Copyright of European Journal of Psychology of Education - EJPE is the property of Instituto Superior de Psicologia Aplicada and its content may not be copied or emailed to multiple sites or posted to a listserv without the copyright holder's express written permission. However, users may print, download, or email articles for individual use. 